\title{
New records of Microtus hyperboreus Vinogradov, 1933 (Rodentia, Arvicolidae) in Chukotka
}

\section{Nikolai E. Dokuchaev \& Igor V. Dorogoy}

\begin{abstract}
New records of Microtus hyperboreus in Chukotka extend the range of the species much further to the East and Northeast than was known previously.
\end{abstract}

KEY WORDS: North Siberian vole, Microtus hyperboreus, distribution, North East Asia, Chukotka.

Nikolai E. Dokuchaev [dokuchaev@ibpn.kolyma.ru] \& Igor V. Dorogoy, Institute of Biological Problems of the North, Far East Branch of the Russian Academy of Sciences, ul. Portovaya 18, Magadan 685000, Russia.

\section{Новые находки Microtus hyperboreus Vinogradov, 1933 (Rodentia, Arvicolidae) на Чукотке}

\author{
Н.Е. Докучаев, И.В. Дорогой
}

РЕЗЮМЕ. Получены новые данные о распространении северосибирской полевки на Чукотке. Установлено, что область распространения данного вида простирается гораздо дальше на восток и северо-восток, чем считалось раньше.

КЛЮЧЕВЫЕ СЛОВА: северосибирская полевка, Microtus hyperboreus, распространение, СевероВосточная Азия, Чукотка.

The North Siberian vole (Microtus hyperboreus Vinogradov, 1933) remains till now a least investigated mammal species in North East Asia. The range borders of this species in this region is not adequately known. According Gromov \& Erbaeva (1995), the range of North Siberian vole reaches from the Lower Yenisey River in the West up to the Uppers Indigirka and Kolyma rivers (Yano-Oimyakonskoe Nagorie (upland) and Yukagirskoe Ploskogorie (plateau)) in the East. In the same time there is an opinion (Pozdnyakov et al., 1998; Litvinov, 2001) that western border of M. hyperboreus range extends to the East from Yana River, and the information on its collecting on Taimyr and Lower Olenek River based on incorrect specimen identification. East border of North Siberian vole distribution generally is designated rather schematically that is the result of scarce number of localities in North East Asia where this vole was collected (Chereshnev, 1996).

Until recently in the Chukotskii Autonomnyi Okrug (Chukchi Autonomous District) North Siberian vole was collected only in its extremely western limits in Omolon River basin (Chernyavski et al., 1978; Fig. 1, sites 1 and 2). In 2003 M. hyperboreus for the first time was found in two sites in the upper part of Anadyr River (Fig. 1, sites 3 and 4; Dokuchaev \& Dorogoy, in press). As a result the northeastern border of $M$. hyperboreus range was extended almost on $400 \mathrm{~km}$. In 2004 North Siberian vole was found in the upper part of Keveem River, running into the Nolde inlet at the coast of the Arctic Ocean (Fig. 1, site 5). These new findings essentially specify our knowledge on distribution of $M$. hy- perboreus in eastern and northeastern parts of its range. In Upper Anadyr North Siberian voles were collected during August 5-11, 2003. They were caught in the valley of Srednii Kaiemravaam stream (the left inflow of Mechkereva River, N 66²4', E 169³4'). The skulls of North Siberian vole were also found by us among the Microtus sample from the mouth of Balaganchik River $\left(\mathrm{N} \mathrm{64^{ \circ }} 55^{\prime}, \mathrm{E} 168^{\circ} 34^{\prime}\right)$. The researches in the last area were carried out in 1986-1991 under a management of V.G. Krivosheev. During June 16-21, 2004 two North Siberian voles were caught by I.V. Dorogoy in the basin of Keveem River (N 68 $8^{\circ} 8^{\prime}$, E 173 ${ }^{\circ} 42^{\prime}$ ). All specimens of $M$. hyperboreus are kept in the collection of the Institute of Biological Problems of the North, Far East Branch of the Russian Academy of Sciences, Magadan (IBPN 6027-6036).

The snap traps lines with a bait from peanut butter put for a night in basic biotops for small mammals catching. In the valley of Srednii Kaiemravaam stream 160 trap-nights, and in Keveem River 215 ones were fulfilled.

In the basin of Srednii Kaiemravaam stream all six specimens of $M$. hyperboreus were caught on a place with middle humidified moss-sedge (Carex) - cottongrass (Eriophorum) tundra in the upper part of a valley slope (Fig. 2A). Relative density of North Siberian vole here was $10 \%$. Simultaneously there were collected Mountain vole (Alticola lemminus Miller, 1899), Northern Red-backed vole (Clethrionomys rutilus Pallas, 1779), and Brown Lemming (Lemmus trimucronatus Richardson, 1825). In the basin of Keveem River $M$. 


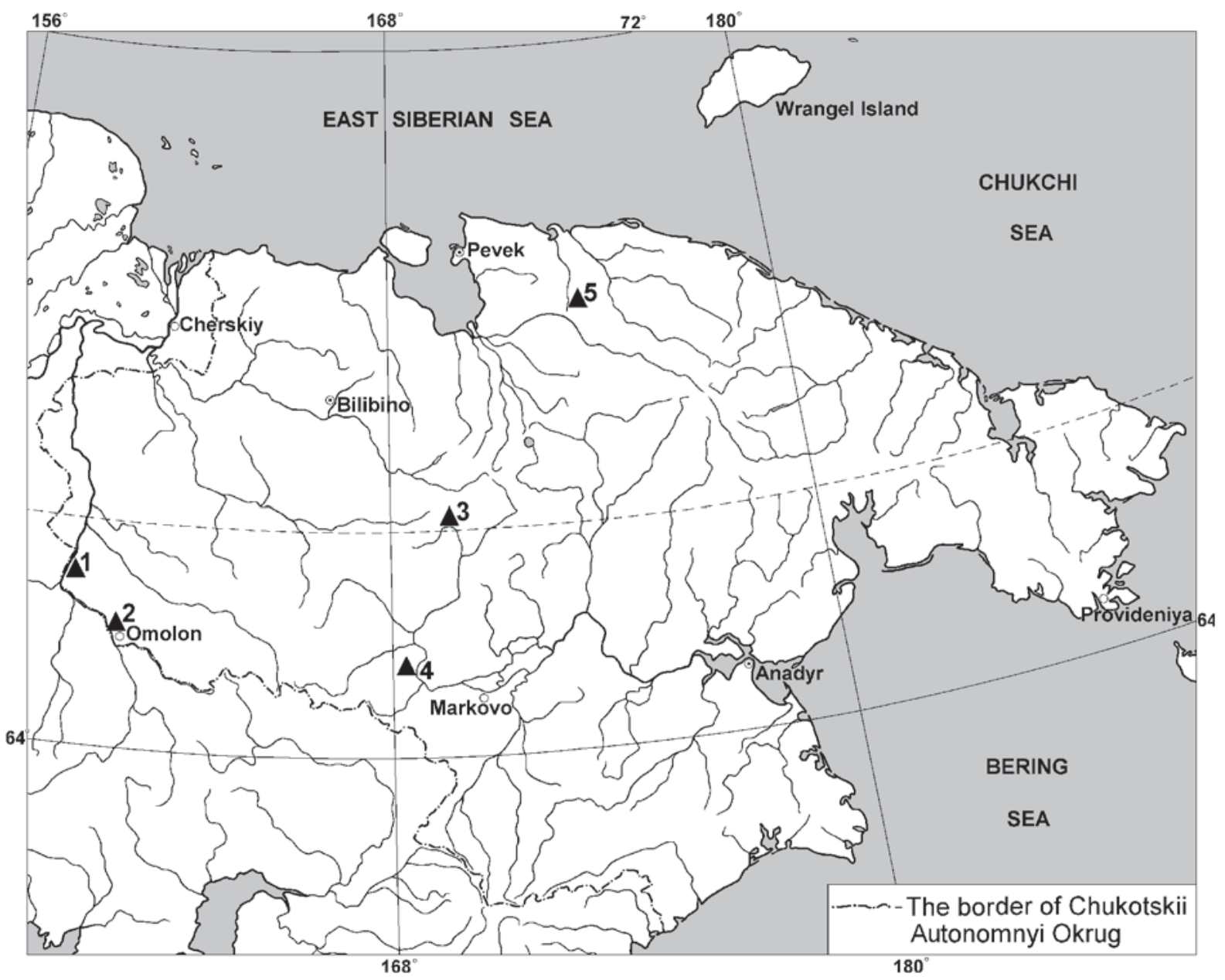

Figure 1. Map of collecting sites of Microtus hyperboreus in Chukotka (see text for the explanation).

hyperboreus was collected in hummock shrubby-cotton-grass tundra (Fig. 2A). Relative density of this vole was $2.2 \%$. Brown lemmings, Northern Red-backed voles, and Grey-sided voles (Clethrionomys rufocanus Sundevall, 1846) were caught together with North Siberian vole. Tundra vole (Microtus oeconomus Pallas, 1776) occupied here more humid areas. All of them were caught in flood-lands in place with sedge-cottongrass tundra and dwarf birch. The relative density of tundra vole was more than three times greater than for North Siberian vole (7.5\%). This shows that North Siberian and Tundra voles inhabit different biotops.

New data collected by us testify that the North-East border of North Siberian vole distribution is situated much further, than it was considered previously. Additional investigation of $M$. hyperboreus distribution in North East Asia is needed.

\section{References}

Chereshnev I.A. (ed.). 1996. [Vertebrate animals of NorthEast Russia]. Vladivostok: Dal'nauka. 308 p. [in Russian].

Chernyavski F.B., Dokuchaev N.E. \& Korolenko G.E. 1978. [The mammals of the middle part of Omolon River] // [The fauna and biogeography of mammals in North-East Siberia]. Vladivostok: FEB AN USSR. P.26-65 [in Russian].

Dokuchaev N.E. \& Dorogoy I.V. in press. [New data on small mammals of Anadyr River basin] // Zoologicheskii Zhurnal

Gromov I.M. \& Erbaeva M.A. 1995. [The mammals of Russia and Adjacent Territories. Lagomorphs and Rodents]. Sankt Peterburg: Zoologicheskii Institute RAN. 522 p. [in Russian].

Litvinov Yu.N. 2001. [Communities and populations of small mammals in the ecosystems of Siberia]. Novosibirsk: TSERIS. 128 p. [in Russian].

Pozdnyakov A.A., Litvinov Yu.N. \& Volpert Ya.L. 1998. [Distribution and intraspecies variety of two close species of the northern voles] // Sibirskii Ecologicheskii Zhurnal. No.3-4. P.337-345 [in Russian]. 

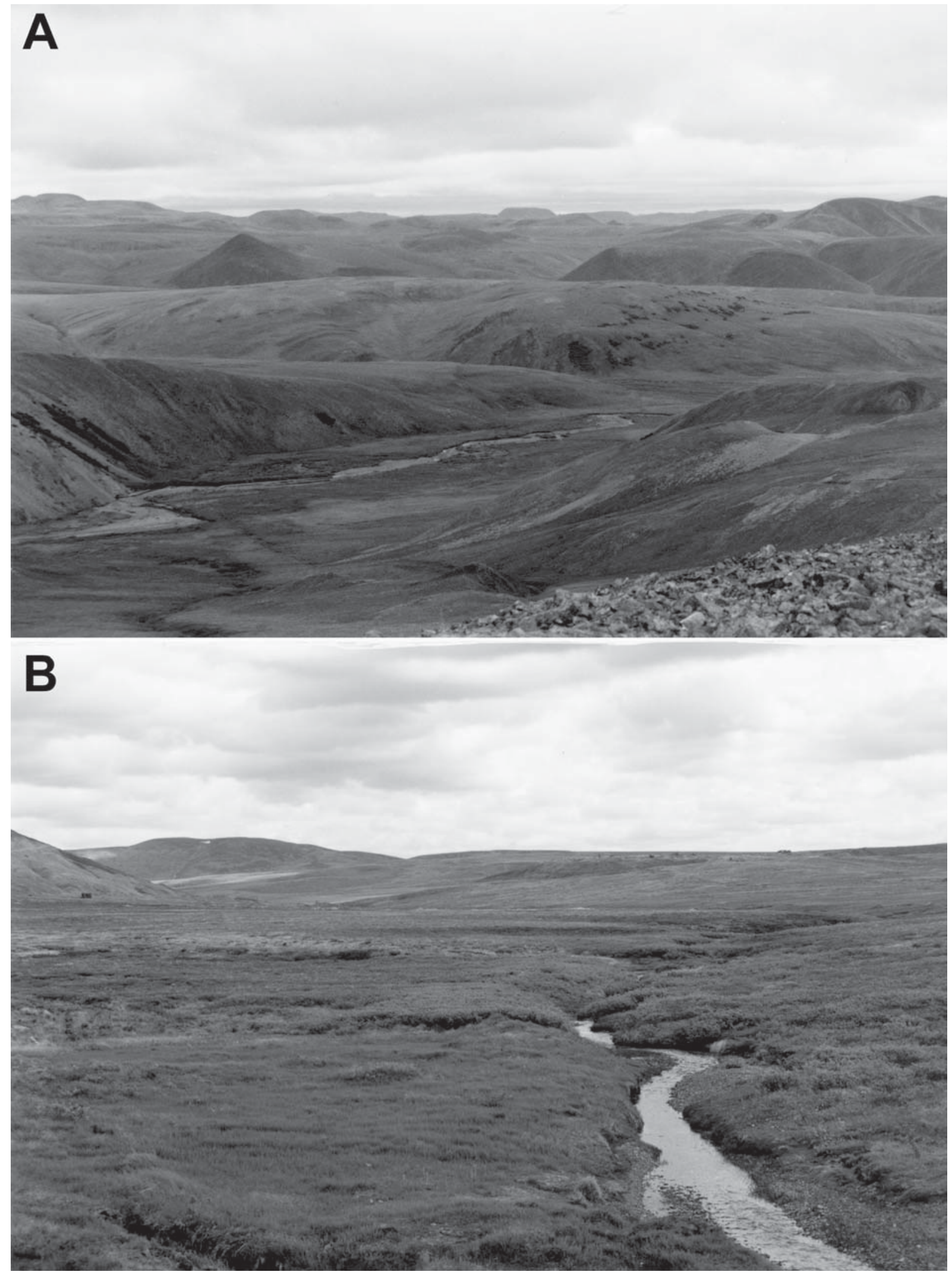

Figure 2. Biotops for Microtus hyperboreus in Upper Anadyr (A) and in Keveem River basin (B). 